\title{
PENGARUH PENERAPAN SISTEM E-FILLING TERHADAP KEPATUHAN WAJIB PAJAK (STUDI KASUS PADA KUPUS II DITKUAD)
}

\author{
Rima Sundari, Monica Subarsa \\ Program Studi D4 Akuntansi Keuangan, Politeknik Pos Indonesia \\ rimasundari@poltekpos.ac.id ; subarsamonca@gmail.com
}

\begin{abstract}
ABSTRAK
Seorang wajib pajak diharuskan untuk mematuhi kepatuhan wajib pajaknya sesuai dengan ketentuan peraturan perundang-undangan dan peraturan pelaksanaan perpajakan yang berlaku. Salah satunya yaitu kepatuhan wajib pajak dalam melaporkan SPT. Dengan adanya $e$-filling diharapkan dapat mempermudah seorang wajib pajak dalam melaporkan SPTnya, maka dari itu penelitian ini dilakukan dengan tujuan untuk mengetahui pengaruh penerapan sistem e-filling terhadap kepatuhan wajib pajak di KUPUS II DITKUAD. Metode yang digunakan dalam penelitian ini adalah kuantitatif asosiatif. Data yang digunakan adalah data primer yang diperoleh melalui kuesioner yang dibagikan kepada 65 responden yang merupakan wajib pajak orang pribadi yang bekerja di KUPUS II DITKUAD. Alat analisis yang digunakan yaitu uji valditas, uji reliabilitas, analisis korelasi spearman rank, analisis regresi linier sederhana, uji koefisien determinasi, dan uji t. Hasil penelitian menunjukan bahwa penerapan sistem e-filling berpengaruh signifikan terhadap kepatuhan wajib pajak pada KUPUS II DITKUAD.

Kata kunci : Sistem E-Filling, Kepatuhan Wajib Pajak, SPT.
\end{abstract}

\begin{abstract}
A taxpayer is required to comply with the compliance of his taxpayers in accordance with the provisions of laws and regulations and applicable tax implementation regulations. One of them is taxpayer compliance in reporting SPT. With the existence of efilling is expected to facilitate a taxpayer in reporting his SPT, therefore this research was conducted with the aim of knowing the effect of implementing the e-filling system on taxpayer compliance in KUPUS II DITKUAD. The method used in this research is quantitative associative. The data used is primary data obtained through questionnaires distributed to 65 respondents who are individual taxpayers who work in KUPUS II DITKUAD. The analytical tools used are validity test, reliability test, Spearman rank correlation analysis, simple linear regression analysis, coefficient of determination test, and $t$ test. The results showed that the implementation of the e-filling system had a positif and significant effect on taxpayer compliance at KUPUS II DITKUAD.

Keywords : E-Filling System, Taxplayer Compliance, SPT.
\end{abstract}




\section{PENDAHULUAN}

Indonesia merupakan negara hukum berdasarkan Pancasila dan Undang-Undang Dasar 1945, yang bertujuan untuk mewujudkan tata kehidupan negara dan bangsa yang adil, sejahtera, aman, tenteram, dan tertib, serta menjamin kedudukan hukum yang sama bagi warga masyarakat. Untuk mencapai tujuan yang dimaksud, pembangunan nasional yang dilakukan di seluruh tanah air memerlukan biaya besar yang harus digali terutama dari sumber kemampuan sendiri. Pajak merupakan salah satu usaha yang digunakan oleh pemerintah untuk mewujudkan kemandirian suatu bangsa atau negara dalam pembiayaan pembangunan yang berguna bagi kepentingan bersama, seperti fasilitas umum dan infrastruktur suatu negara dengan tujuan untuk mensejahterakan masyarakat umum. Pajak juga merupakan pungutan yang mengurangi penghasilan wajib pajak pribadi maupun wajib pajak badan.

Sejak tahun 1983, pemerintah Indonesia telah mengubah sistem pemungutan pajak yang semula menggunakan official assessment system (dipakai saat era kolonial Belanda) menjadi self assessment system. Dimana pada official assessment system, tanggung jawab pungutan pajaknya terletak sepenuhunya pada pemerintahan, sedangkan untuk selfassessment system kepercayaan diberikan kepada wajib pajak untuk menghitung, memperhitungkan, membayar, dan melaporkan sendiri jumlah pajak yang seharusnya terutang berdasarkan peraturan perundang-undangan perpajakan. Dengan digantinya sistem pemungutan pajak menjadi self assessment system maka diharapkan wajib pajak akan lebih mandiri dan aktif dalam melaksanakan kewajiban perpajakannya, serta diharapkan dapat meningkatkan kepatuhan wajib pajak.

Namun seperti yang dilansir dari (Prastowo, 2017) "kepatuhan pajak Indonesia masih terbilang rendah, yang tergambarkan dalam stagnasi tax ratio yang masih berada di bawah negara lain pada kisaran 12-13 persen. Capaian tax ratio Indonesia masih di bawah Filipina (14 persen), Malaysia (16 persen), Thailand (17 persen), Korea Selatan (25 persen), Afrika Selatan (27 persen), dan Brasil (34 persen), atau setara negara berpenghasilan menengah-bawah (17 persen)." Maka dari itu untuk meningkatkan kepatuhan Wajib Pajak, Direktorat Jenderal Pajak selalu berupaya mengoptimalkan pelayanan sehingga diharapkan dapat meningkatkan kesadaran dan keinginan masyarakat untuk tertib sebagai Wajib Pajak, salah satunya dengan melakukan reformasi perpajakan yaitu dengan memanfaatkan teknologi informasi dan komunikasi dengan menerapkan sistem e-filling. "Melalui Keputusan Direktur Jenderal Pajak Nomor Kep-88/PJ/2004 pada bulan Mei tahun 2004 secara resmi diluncurkan produk e-filling. Tepatnya pada tanggal 24 Januari 2005 bertempat di Kantor Kepresidenan, Presiden Republik Indonesia bersama-sama dengan Direktorat Jenderal Pajak meluncurkan produk e-filling atau electronic filling system" Ayu dalam (Lado \& Budiantara, 2018).

E-filling merupakan layanan pengisian dan penyampaian Surat Pemberitahuan Wajib Pajak yang dilakukan secara elektronik melalui sistem online yang real time kepada Direktorat Jenderal Pajak melalui internet pada website Direktorat Jenderal Pajak atau melalui Penyedia Jasa Aplikasi yang telah ditunjuk oleh Direktorat Jenderal Pajak. Sehingga penerapan sistem $e$-filling ini diharapkan dapat membantu, dan mempermudah wajib pajak, karena penggunaan e-filling dapat digunakan kapan saja dan dimana saja, sehingga penggunaannya dapat meminimalkan biaya dan waktu dalam penghitungan, pengisian, serta pelaporan SPT.

Dalam (Santoso, 2021) hingga tanggal 25 Februari 2021, DJP mencatat realisasi penyampaian SPT tahunan untuk pajak penghasilan $(\mathrm{PPh})$ tahun pajak 2020 sudah masuk sebanyak 3.271.915 SPT Tahunan. Bila dibandingkan dengan periode sama tahun lalu yang sebesar 3.411.707, maka jumlah pelapor SPT tahunan lebih rendah 140.392 atau setara $4,11 \%$. Sebagian besar dari wajib pajak melaporkan SPT tahunannya secara online melalui 
e-filling, yaitu sebanyak 3.124.946 orang atau setara 95,5\% dari total SPT Tahunan yang masuk. Jumlah tersebut juga lebih rendah bila dibandingkan dengan periode yang sama tahun lalu, di mana jumlah wajib pajak yang melaporkan SPT lewat $e$-filling sebanyak 3.221.887 WP. Sementara itu, sebanyak 146.969 WP atau setara 4,4\% dari total SPT, melaporkan SPT tahunan secara manual.

Sementara itu, dilansir dari (Humas Kemenkeu, 2021) menteri keuangan mengimbau agar masyarakat melaporkan SPT melalui daring atau $e$-filling demi mencegah penyebaran virus COVID-19.

\section{Perkembangan Penerimaan SPT Tahunan \\ Tahun 2021 \\ Data update 8 Maret 2021}

\begin{tabular}{|c|l|c|c|}
\hline \multirow{2}{*}{ No } & \multirow{2}{*}{ Metode Pelaporan SPT } & \multicolumn{2}{|c|}{ Jumlah } \\
\cline { 3 - 4 } & & 2020 & 2021 \\
\hline 1 & E-Filling ASP & 0 & 10,220 \\
\hline 2 & E-Filling DJP & $5,340,497$ & $4,640,533$ \\
\hline 3 & E-Form & 331,119 & 266,037 \\
\hline 4 & E-SPT & 63,084 & 40,380 \\
\hline 5 & Manual & 252,521 & 194,836 \\
\hline \multicolumn{2}{|c|}{ Total } & $5,987,221$ & $5,152,006$ \\
\hline
\end{tabular}

\section{Gambar 1 \\ Perkembangan Penerimaan SPT Tahunan}

Sumber: (Humas Kemenkeu, 2021)

Berdasarkan data Direktorat Jenderal Pajak (DJP), hingga 8 Maret 2021, jumlah SPT yang masuk sebanyak 5.152.006, di mana 96 persen disampaikan melalui $e$-filling dan sisanya secara manual. Kepatuhan penyampaian SPT menjadi poin penting untuk peningkatan penerimaan pajak dan dalam jangka panjang mampu untuk peningkatan kemandirian bangsa. Bila dibandingkan dengan Tahun 2020 dengan metode pelaporan SPT menggunakan sistem $e$-filling yang tercatat sebesar 5.734.700 WP, maka tingkat pelaporan SPT Tahun 2021 dengan menggunakan sistem e-filling mengalami penurunan dengan jumlah pelapor sebanyak 4.957.170 WP.

Terdapat beberapa penelitian terdahulu yang telah membahas mengenai kepatuhan Wajib Pajak, diantaranya penelitian yang memiliki hasil sejenis yang dilakukan oleh Indri Setiyarani (2017), Yuliano Osvaldo Lado dan M Budiantara (2018), dan Gilbert Dwi Reinaldo Manullan, Putu Eka Dianita Marvilianti Dewi dan I Nyoman Putra Yasa (2020) dengan hasil penelitian yang menunjukkan bahwa penerapan sistem e-filling berpengaruh positif signifikan terhadap kepatuhan Wajib Pajak.

Penelitian sejenis lainnya dengan hasil yang berbeda yaitu penelitian yang dilakukan oleh Kartika Ratna Handayani dan Sihar Tambun (2016), dimana pada penelitian tersebut menghasilkan penelitian bahwa penerapan sistem e-filling tidak berpengaruh signifikan terhadap kepatuhan wajib pajak dan Reza Yunanto (2015) dalam penelitiannya menyimpulkan bahwa tidak terdapat perbedaan antara kepatuhan penyampaian SPT Tahunan PPh WPOP di KPP Pratama Sleman sebelum dan sesudah penerapan $e$-filling melalui website DJP.

\section{Identifikasi Masalah}

Berdasarkan latar belakang di atas, maka yang menjadi identifikasi masalah pada penelitian ini adalah sebagai berikut :

1. Bagaimana penerapan sistem $e$-filling pada KUPUS II DITKUAD ?

2. Bagaimana kepatuhan wajib pajak pada KUPUS II DITKUAD ? 
3. Bagaimana pengaruh penerapan sistem e-filling terhadap kepatuhan wajib pajak KUPUS II DITKUAD ?

\section{KAJIAN PUSTAKA}

1. Pajak

a. Pengertian Pajak

Menurut Prof. Dr. Rochmat Soemitro, SH dalam (Mardiasmo, 2019) "Pajak ialah iuran rakyat kepada kas negara yang berdasarkan undang - undang (yang dapat dipaksakan) dengan tidak mendapatkan jasa timbal balik (kontraprestasi) yang langsung dapat ditunjukan dan yang digunakan unuk membayar pengeluaran secara umum."

Pada Pasal 1 Ayat 1 Undang-Undang Nomor 16 tahun 2009 tentang Ketentuan Umum dan Tata Cara Perpajakan "Pajak adalah kontribusi wajib kepada negara yang terutang oleh orang pribadi atau badan yang bersifat memaksa berdasarkan UndangUndang, dengan tidak mendapat imbalan secara langsung dan digunakan untuk keperluan negara bagi sebesar-besarnya kemakmuran rakyat."

Sedangkan menurut (Resmi, 2017) "Pajak sebagai suatu kewajiban menyerahkan sebagian dari kekayaan kepada kas negara yang disebabkan dalam suatu keadaan, kejadian, dan perbuatan yang diberikan kedudukan tertentu, tetapi bukan sebagai hukuman, menurut peraturan yang ditetapkan pemerintah serta dapat dipaksakan, tetapi pajak sendiri tidak mendapat jasa timbal balik dari negara. Secara langsung hal ini berguna untuk memelihara kesejahtreraan secara umum."

b. Fungsi Pajak

Pajak memiliki fungsi-fungsi yang dapat digunakan untuk menunjang tercapainya kesejahteraan masyarakat yang adil dan hidup sejahtera. Maka dari itu terdapat dua fungsi pajak menurut (Mardiasmo, 2019), yaitu :

1. Fungsi anggaran (Budgetair)

Pajak berfungsi sebagai salah satu sumber dana bagi pemerintah untuk membiayai pengeluaran-pengeluarannya.

2. Fungsi Mengatur (Regulerend)

Pajak berfungsi sebagai alat untuk mengatur atau melaksanakan kebijaksanaan pemerintah dalam bidang sosial dan ekonomi.

c. Sistem Pamungutan Pajak sistem, yaitu :

Menurut (Mardiasmo, 2019) sistem pemungutan pajak terbagi menjadi beberapa

\section{Official Assessment System}

Adalah suatu sistem pemungutan yang memberi ewenang kepada pemerintah (fiskus) untuk menentukan besarnya pajak yang terutang oleh Wajib Pajak.

2. Self Assessment System

Adalah suatu sistem pemungutan pajak yang memberi wewenang kepada Wajib

Pajak untuk menentukan sendiri besarnya pajak yang terutang.

3. Withholding System

Adalah suatu sistem pemungutan pajak yang memberi wewenang kepada pihak ketiga (bukan fiskus dan bukan Wajib Pajak yang bersangkutan) untuk memotong atau memungut pajak terutang oleh Wajib Pajak.

\section{Kepatuhan Wajib Pajak}

a. Pengertian Wajib Pajak

Menurut Undang-Undang No 16 Tahun 2009 tentang Ketentuan Umum dan Tata Cara Perpajakan "Wajib Pajak adalah orang pribadi atau badan, meliputi pembayar pajak, pemotong pajak, dan pemungut pajak, yang mempunyai hak dan kewajiban perpajakan sesuai dengan ketentuan peraturan perundang-undangan perpajakan." 
Sedangkan menurut Diana \& Setiawati dalam (Lado \& Budiantara, 2018) "Wajib Pajak adalah orang pribadi atau badan, meliputi pembayar pajak, pemotong pajak dan pemungut pajak, yang mempunyai hak dan kewajiban perpajakan sesuai dengan ketentuan peraturan perundang-undangan perpajakan."

b. Pengertian Kepatuhan Wajib Pajak

Menurut Siti Kurnia dalam (Nurlaela, 2017), menyatakan bahwa "kepatuhan perpajakan adalah tindakan wajib pajak dalam pemenuhan kewajiban perpajakannya sesuai dengan ketentuan peraturan perundang-undangan dan peraturan pelaksanaan perpajakan yang berlaku dalam suatu negara." Sedangkan menurut Rahman dalam (Lado \& Budiantara, 2018) "kepatuhan perpajakan dapat didefinisikan sebagai keadaan dimana Wajib Pajak memenuhi semua kewajiban perpajakan dan melaksanakan hak perpajakannya."

c. Syarat Menjadi Wajib Pajak Patuh

Berdasarkan Peraturan Menteri Keuangan Nomor 74/KMK.03/2012 tentang Tata Cara Penetapan dan Pencabutan Penetapan Wajib Pajak Dengan Kriteria Tertentu Dalam Rangka Pengembalian Pendahuluan Kelebihan Pembayaran Pajak, Wajib Pajak dengan kriteria tertentu disebut sebagai Wajib Pajak Patuh apabila memenuhi beberapa syarat sebagai berikut:

1. Tepat waktu dalam menyampaikan Surat Pemberitahuan; tepat waktu dalam penyampaian Surat Pemberitahuan Tahunan dalam tiga tahun terakhir yaitu akhir bulan ketiga setelah tahun pajak.

2. Tidak mempunyai tunggakan pajak untuk semua jenis pajak, kecuali tunggakan pajak yang telah memperoleh izin menganggur atau menunda pembayaran pajak. Tunggakan pajak adalah angsuran pajak yang belum dilunasi pada saat atau setelah tanggal pengenaan denda.

3. Laporan keuangan harus diaudit oleh Akuntan Publik atau Lembaga Pengawas Keuangan Pemerintah dengan pendapat Wajar Tanpa Pengecualian selama tiga tahun berturut-turut. Pendapat Wajar Tanpa Pengecualian diberikan oleh auditor apabila tidak ditemukan kesalahan material secara menyeluruh dalam laporan keuangan yang disajikan, dengan kata lain laporan keuangan tersebut sudah sesuai dengan Standar Akuntansi Keuangan (SAK).

4. Tidak pernah dipidana karena melakukan tindak pidana di bidang perpajakan berdasarkan keputusan pengauditan yang mempunyai kekuatan hukum tetap dalam jangka waktu lima tahun terakhir.

\section{Penerapan Sistem E-Filling}

a. Pengertian E-Filling

Melalui Keputusan Direktorat Jenderal Pajak (DJP) Nomor Kep-88/PJ/2004 pada bulan Mei tahun 2004 secara resmi sistem e-filing diluncurkan. Menurut Peraturan Direktorat Jenderal Pajak No 47/PJ/2008 pasal 1 menyebutkan bahwa e-filing adalah suatu cara penyampaian SPT dan penyampaian pemberitahuan perpanjangan SPT Tahunan secara elektronik yang dilakukan secara online dan real time melalui Penyedia Jasa Aplikasi (ASP).

Menurut Pandiangan dalam (Noviani, 2018) mendefinisikan sistem e-filing adalah suatu cara penyampaian Surat Pemberitahuan (SPT) yang dilakukan melalui sistem berbasis internet dan secara cepat. E-Filling dijelaskan oleh Gita dalam (Lado \& M. Budiantara, 2018) sebagai suatu layanan penyampaian SPT secara elektronik baik untuk Orang Pribadi maupun Badan melalui internet pada website Direktorat Jenderal Pajak atau penyedia jasa aplikasi kepada Kantor Pajak dengan memanfaatkan internet, sehingga Wajib Pajak tidak perlu mencetak semua formulir laporan dan menunggu tanda terima secara manual. 
Sedangkan pendefinisan e-filling menurut Rahayu dalam (Nurlaela, 2017), efilling merupakan cara pelaporan SPT dengan sistem online dan Real Time dimana penyampaian dapat dilalukan melalui ASP yang ditunjuk oleh DJP sebagai perusahaan yang menerima penyampaian.

b. Keuntungan E-Filling

Menurut situs Direktorat Jenderal Pajak dalam artikel kemenkeu.go.id (Kementerian Keuangan RI, 2018) terdapat tujuh keuntungan jika menggunakan fasilitas sistem $e$-filling yaitu :

1. Penyampaian SPT dapat dilakukan secara cepat, aman, dan kapan saja.

2. Murah, tidak dikenakan biaya pada saat pelaporan SPT.

3. Penghitungan dilakukan secara tepat karena menggunakan sistem komputer.

4. Kemudahan dalam mengisi SPT karena pengisian SPT dalam bentuk wizard..

5. Data yang disampaikan WP selalu lengkap karena ada validasi pengisian SPT.

6. Ramah lingkungan dengan mengurangi penggunaan kertas.

7. Dokumen pelengkap (fotokopi Formulir 1721 A1/A2 atau bukti potong PPh, SSP

Lembar ke-3 PPh Pasal 29, Surat Kuasa Khusus, perhitungan PPh terutang bagi

WP Kawin Pisah Harta dan/atau mempunyai NPWP sendiri, fotokopi Bukti Pembayaran Zakat) tidak perlu dikirim lagi kecuali diminta oleh KPP melalui Account Representative (AR).

c. Penerapan Sistem E-Filling

Pengertian penerapan menurut Kamus Besar Bahasa Indonesia adalah proses, cara, perbuatan menerapkan, pemasangan, pemanfaatan. Sedangkan enurut Peraturan Direktorat Jenderal Pajak No 47/PJ/2008 pasal 1 menyebutkan bahwa e-filing adalah suatu cara penyampaian SPT dan penyampaian pemberitahuan perpanjangan SPT Tahunan secara elektronik yang dilakukan secara online dan real time melalui Penyedia Jasa Aplikasi (ASP).

Maka dari itu, dapat disimpulkan bahwa penerapan sistem e-filling adalah suatu proses atau cara memanfaatkan sistem yang digunakan untuk menyampaikan SPT secara online yang realtime yang diterapkan oleh Direktorat Jenderal Pajak.

\section{METODE PENELITIAN}

Penelitian ini merupakan jenis penelitian yang menggunakan metode penelitian kuantitatif, dimana menurut (Sugiyono, 2019) "Metode kuantitatif disebut sebagai metode pasitivistik karena berlandasan pada filsafat positivisme. Metode ini sebagai metode ilmiah karena telah memunuhi kaidah ilmiah yaitu empiris, objektif, terukur, rasional, dan sistematis. Metode ini juga disebut metode discovery, karena dengan metode ini ditemukan dan dikembangkan berbagai iptek baru. Metode ini disebut metode kuantitaif karena data dan penelitian berupa angka dan analisis menggunakan statistik."

Dalam penelitian ini data yang digunakan merupakan data primer. Dimana menurut (Sugiyono, 2019) "sumber primer adalah sumber data yang langsung memberikan data kepada pengumpul data". Sumber data primer pada penelitian ini dikumpulkan dengan menggunakan kuesioner yang disebarkan kepada responden. Teknik sampling yang digunakan pada penelitian ini yaitu probability sampling dengan pengambilan sampel dilakukan secara simple random sampling. Populasi dalam penelitian ini adalah seluruh Wajib Pajak Orang Pribadi Pegawai KUPUS II DITKUAD yang berjumlah 79 orang. Sedangkan sampel yang digunakan yaitu berjumlah 65 sampel. Alat analisis data yang digunakan yaitu uji valditas, uji reliabilitas, analisis korelasi spearman rank, analisis regresi linier sederhana, uji koefisien determinasi, dan uji t.

\section{HASIL DAN PEMBAHASAN}




\section{Uji Validitas}

Dalam penelitian ini, pengujian validitas berupa kuesioner yang terdiri atas 18 pernyataan dengan pembagian 12 pernyataan untuk Penerapan Sistem E-Filling (X), dan 6 pernyataan untuk Kepatuhan Wajib Pajak (Y). Pada penelitian ini sampel berjumlah 65 responden. Sehingga diperoleh $\mathrm{r}$ tabel sebesar 0,244.

Berdasarkan tabel hasil uji validitas, seluruh item pernyataan pada variabel $\mathrm{X}$ dan $\mathrm{Y}$ dinyatakan valid karena hasil $\mathrm{r}$ hitung lebih besar daripada $\mathrm{r}$ tabel $(0,244)$. Sehingga dapat disimpulkan bahwa sebanyak 18 pernyataan dalam kuesioner ini telah valid dan dapat digunakan dalam penelitian.

\section{Uji Reliabilitas}

Tabel 1

Hasil Uji Realiabilitas Penerapan Sistem E-Filling (X) dan Kepatuhan Wajib Pajak (Y)

\begin{tabular}{|c|c|c|c|}
\hline Variabel & $\begin{array}{c}\text { Cronbach's } \\
\text { Alpha }\end{array}$ & $\begin{array}{c}\text { Cronbach's } \\
\text { Alpha Standart }\end{array}$ & Keterangan \\
\hline $\begin{array}{c}\text { Penerapan Sistem } \\
\text { E-Filling (X) }\end{array}$ & 0,945 & 0,60 & Reliabel \\
\hline $\begin{array}{c}\text { Kepatuhan Wajib } \\
\text { Pajak (Y) }\end{array}$ & 0,949 & 0,60 & Reliabel \\
\hline \multicolumn{4}{|c}{ Sumber : Pengolahan data SPSS }
\end{tabular}

Berdasarkan tabel diatas terlihat bahwa nilai Cronbach's Alpha Penerapan Sistem E-Filling sebesar 0,945, dan nilai Cronbach's Alpha Kepatuhan Wajib Pajak sebesar 0,949. Hal ini menunjukan bahwa nilai Cronbach's Alpha Penerapan Sistem E-Filling (X) dan Kepatuhan Wajib Pajak (Y) > 0,60 maka kedua variabel dalam penelitian ini dikatakan reliabel.

\section{Analisis Korelasi Spearman Rank}

Tabel 2

Hasil Uji Analisis Korelasi Spearman Rank Penerapan Sistem E-Filling (X) dan Kepatuhan Wajib Pajak (Y)

\begin{tabular}{|c|c|c|c|c|}
\hline & & & $\begin{array}{c}\text { Penerapan } \\
\text { Sistem E-Filling }\end{array}$ & $\begin{array}{l}\text { Kepatuhan } \\
\text { Wajib Pajak }\end{array}$ \\
\hline \multirow[t]{6}{*}{$\begin{array}{l}\text { Spearman's } \\
\text { rho }\end{array}$} & $\begin{array}{l}\text { Penerapan } \\
\text { Sistem E- } \\
\text { Filling }\end{array}$ & $\begin{array}{l}\text { Correlation } \\
\text { Coefficient }\end{array}$ & 1,000 &, $643^{* *}$ \\
\hline & & $\begin{array}{l}\text { Sig. (2- } \\
\text { tailed) }\end{array}$ & & 0,000 \\
\hline & & $\mathrm{N}$ & 65 & 65 \\
\hline & $\begin{array}{l}\text { Kepatuhan } \\
\text { Wajib Pajak }\end{array}$ & $\begin{array}{l}\text { Correlation } \\
\text { Coefficient }\end{array}$ &, $643^{* *}$ & 1,000 \\
\hline & & $\begin{array}{l}\text { Sig. (2- } \\
\text { tailed) }\end{array}$ & 0,000 & \\
\hline & & $\mathrm{N}$ & 65 & 65 \\
\hline
\end{tabular}

Hasil perhitungan menggunakan SPSS for windows version 26 menghasilkan nilai signifikansi sebesar 0,000, yang dimana itu berarti nilai signifikansi $(0,000)<0,05$ sehingga dapat dikatakan bahwa data berkorelasi. Selain itu, untuk nilai korelasi spearman rank antara variabel Penerapan Sistem E-Filling (X) dan variabel Kepatuhan Wajib Pajak 
(Y) menghasilkan angka koefisien korelasi sebesar 0,643. Dimana angka tersebut menunjukkan bahwa tingkat hubungan antara Penerapan Sistem E-Filling (X) dan Kepatuhan Wajib Pajak (Y) memiliki tingkat hubungan yang kuat karena berada diantara $0,60-0,799$.

\section{Analisis Regresi Linier Sederhana}

Tabel 3

Hasil Analisis Regresi Linear Sederhana

\begin{tabular}{|c|c|c|c|c|c|c|}
\hline \multicolumn{7}{|c|}{ Coefficients $^{a}$} \\
\hline \multirow{2}{*}{\multicolumn{2}{|c|}{ Model }} & \multicolumn{2}{|c|}{$\begin{array}{l}\text { Unstandardized } \\
\text { Coefficients }\end{array}$} & \multirow{2}{*}{$\begin{array}{c}\text { Standardized } \\
\text { Coefficients } \\
\text { Beta }\end{array}$} & \multirow[t]{2}{*}{$\mathrm{T}$} & \multirow[t]{2}{*}{ Sig. } \\
\hline & & B & Std. Error & & & \\
\hline 1 & (Constant) & 9,769 & 2,691 & & 3,631 & 0,001 \\
\hline & $\begin{array}{l}\text { Penerapan } \\
\text { Sistem } \\
\text { E-Filling }\end{array}$ & 0,334 & 0,050 & 0,644 & 6,681 & 0,000 \\
\hline
\end{tabular}

Sumber : Data diolah melalui program SPSS for Windows Versions 26.00

Dari hasil output pengolahan data diatas, maka dapat diketahui nilai konstansta (a) sebesar 9,769 dan nilai koefisien regresi (b) sebesar 0,334. Sehingga dapat diketahui persamaan regresi linier sederhana sebagai berikut :

Dari persamaan tersebut dapat diartikan :

$$
\mathrm{Y}=9,769+0,334 \mathrm{X}
$$

1. Jika variabel penerapan sistem $e$-filling $(\mathrm{X})=0$, maka nilai kepatuhan wajib pajak (Y) adalah 9,769 .

2. Jika nilai penerapan sistem e-filling (X) bertambah 1, maka nilai kepatuhan wajib pajak (Y) akan bertambah 0,334.

Karena koefisien regresi bernilai positif maka dapat disimpulkan bahwa penerapan sistem $e$-filling (X) berpengaruh positif terhadap kepatuhan wajib pajak (Y), berarti semakin baik penerapan sistem $e$-filling maka semakin baik pula kepatuhan wajib pajaknya.

\section{Analisis Koefisien Determinasi}

Tabel 4

Hasil Analisis Koefisien Determinasi

\begin{tabular}{|ll|r|r|r|}
\hline \multicolumn{4}{|c|}{ Model Summary } \\
\hline Model & $\mathrm{R}$ & R Square & $\begin{array}{c}\text { Adjusted R } \\
\text { Square }\end{array}$ & $\begin{array}{c}\text { Std. Error of } \\
\text { the Estimate }\end{array}$ \\
\hline 1 &, $644^{\mathrm{a}}$ & 0,415 & 0,405 & 2,091 \\
\hline \multicolumn{4}{|r|}{ a. Predictors: (Constant), Penerapan Sistem E-Filling } \\
\hline
\end{tabular}

Sumber : Data diolah melalui program SPSS for Windows Versions 26.00

Dari tabel diatas dapat dikatakan bahwa besarnya nilai R yaitu sebesar 0,644. Dari output tersebut diperoleh koefisien determinasi ( $R$ Square) sebesar 0,415, yang mengandung pengertian bahwa pengaruh variabel bebas (Penerapan Sistem E-Filling) terhadap variabel terikat (Kepatuhan Wajib Pajak) adalah sebesar 41,5\% dan sisanya 58,5\% dipengaruhi oleh variabel lain yang tidak dimasukkan ke dalam penelitian ini. 


\section{Uji t}

Tabel 5

Hasil Uji t

\begin{tabular}{|l|l|c|c|c|c|c|}
\hline \multicolumn{9}{|c|}{ Coefficients $^{\text {a }}$} \\
\hline \multirow{2}{*}{ Model } & $\begin{array}{c}\text { Unstandardized } \\
\text { Coefficients }\end{array}$ & $\begin{array}{c}\text { Standardized } \\
\text { Coefficients }\end{array}$ & \multirow{2}{*}{ T } & \multirow{2}{*}{ Sig. } \\
\cline { 2 - 5 } & B & $\begin{array}{c}\text { Std. } \\
\text { Error }\end{array}$ & Beta & & \\
\hline 1 & (Constant) & 9,769 & 2,691 & & 3,631 & 0,001 \\
\hline & $\begin{array}{l}\text { Penerapan } \\
\text { Sistem } \\
\text { E-Filling }\end{array}$ & 0,334 & 0,050 & 0,644 & 6,681 & 0,000 \\
& & & & & \\
\hline \multicolumn{2}{|l|}{ a. Dependent Variable: Kepatuhan Wajib Pajak } & & \\
\hline
\end{tabular}

Sumber : Data diolah melalui program SPSS for Windows Versions 26.00

Berdasarkan tabel diatas maka hasil analisis pengujian penerapan sistem $e$-filling terhadap kepatuhan wajib pajak maka diperoleh thitung sebesar 6,681. Pada signifikansi 0,05 dengan derajat kebebasan dk pembilang $=1$, dk penyebut $=63(\mathrm{n}-\mathrm{k}-1)$, dimana $\mathrm{n}=$ jumlah data (65), $\mathrm{k}=$ jumlah variabel X (1), hasil diperoleh untuk tabel sebesar 1,998. Maka analisis uji t tersebut dapat dituliskan dengan $t$ hitung $(6,681)>t$ tabel $(1,998)$, dikarenakan nilai $t$ hitung $>t$ tabel dan angka Sig. $(0,000)<0,05$ maka dari itu dapat disimpulan bahwa Ha diterima dan Ho ditolak yang artinya terdapat pengaruh yang signifikan antara penerapan sistem $e$-filling terhadap kepatuhan wajib pajak di KUPUS II DITKUAD secara parsial.

\section{PEMBAHASAN}

\section{Penerapan Sistem E-Filling pada KUPUS II DITKUAD}

Berdasarkan hasil penyebaran kuesioner kepada 65 orang responden, peneliti mendapatkan tangga pan dari responden yang dimana sebesar $49,2 \%$ responden menjawab sangat setuju, $49 \%$ responden menjawab setuju, 1,3\% responden menjawab ragu-ragu, $0,5 \%$ responden menjawab tidak setuju dan $0 \%$ responden menjawab sangat tidak setuju. Sehingga dapat diperoleh kesimpulan bahwa sebagian besar responden sangat setuju dengan penerapan sistem $e$-filling di KUPUS II DITKUAD.

Selain itu total skor yang didapat dari 12 pernyataan pada variabel penerapan sistem e-filling yaitu sebesar 3486. Hal ini mengartikan bahwa penerapan sistem e-filling pada KUPUS II DITKUAD sudah diterapkan sesuai dengan indikator. Hal tersebut dapat dilihat dari hasil masing-masing indikator penerapan sistem $e$-filling pada garis kontinum berada pada kategori sangat baik.

\section{Kepatuhan Wajib Pajak pada KUPUS II DITKUAD}

Berdasarkan hasil penyebaran kuesioner kepada 65 orang responden, peneliti mendapatkan tanggapan dari responden yang dimana sebesar $61,8 \%$ responden menjawab sangat setuju, $37,4 \%$ responden menjawab setuju, $0,8 \%$ responden menjawab ragu-ragu, maka tidak ada responden yang menjawab tidak setuju dan sangat tidak setuju. Sehingga dapat diperoleh kesimpulan bahwa sebagian besar responden sangat setuju dengan kepatuhan wajib pajak pada KUPUS II DITKUAD.

Selain itu total skor dari 6 pernyataan pada variabel kepatuhan wajib pajak sebesar 1798. Hal ini mengartikan bahwa kepatuhan wajib pajak pada KUPUS II DITKUAD sudah diterapkan sesuai dengan indikator. Hal tersebut dapat dilihat dari hasil masing-masing indikator kepatuhan wajib pajak pada garis kontinum berada pada kategori sangat baik. 


\section{Pengaruh Penerapan Sistem E-Filling terhadap Kepatuhan Wajib Pajak pada KUPUS II DITKUAD}

Berdasarkan hasil penelitian penerapan sistem $e$-filling terhadap kepatuhan wajib pajak menggunakan program SPSS for Windows Versions 26.00 pada uji analisis korelasi spearman rank menghasilkan nilai signifikansi sebesar 0,000, yang dimana itu berarti nilai signifikansi $(0,000)<0,05$ sehingga dapat dikatakan bahwa kedua data berkorelasi. Selain itu, untuk nilai korelasi spearman rank antara variabel Penerapan Sistem E-Filling (X) dan variabel Kepatuhan Wajib Pajak (Y) menghasilkan angka koefisien korelasi sebesar 0,643. Dimana angka tersebut menunjukkan bahwa tingkat hubungan antara Penerapan Sistem $E$ Filling (X) dan Kepatuhan Wajib Pajak (Y) memiliki tingkat hubungan yang kuat karena berada diantara 0,60-0,799 pada tabel. Maka dapat disimpulkan bahwa Penerapan Sistem E-Filling (X) dan Kepatuhan Wajib Pajak (Y) memiliki tingkat hubungan yang kuat.

Berdasarkan hasil uji analisis regresi linear sederhana yang dilakukan dapat ditarik dalam bentuk persamaan regresi linear $\mathrm{Y}=9,769+0,344 \mathrm{X}$. Berdasarkan perhitungan regresi dapat diartikan jika penerapan sistem e-filling $(\mathrm{X})$ mengalami kenaikan 1, maka kepatuhan wajib pajak (Y) akan mengalami kenaikan sebesar 0,334. Maka dapat disimpulan juga bahwa apabila terjadi kenaikan terhadap penerapan sistem e-filling (X) maka kepatuhan wajib pajak (Y) juga mengalami kenaikan, dan karena koefisien bernilai positif maka dapat disimpulkan bahwa penerapan sistem $e$-filling $(\mathrm{X})$ memiliki hubungan positif dengan kepatuhan wajib pajak (Y), itu berarti semakin baik penerapan sistem $e$ filling maka semakin baik pula kepatuhan wajib pajak.

Berdasarkan hasil analisis koefisien determinasi menghasilkan besarnya nilai $\mathrm{R}$ yaitu sebesar 0,644. Dari output tersebut diperoleh koefisien determinasi (R Square) sebesar 0,415 , yang mengandung pengertian bahwa pengaruh variabel bebas (Penerapan Sistem $E$ Filling) terhadap variabel terikat (Kepatuhan Wajib Pajak) adalah sebesar $41,5 \%$ dan sisanya $58,5 \%$ dipengaruhi oleh variabel lain yang tidak dimasukkan ke dalam penelitian ini.

Berdasarkan hasil perhitungan uji t maka diperoleh $\mathrm{t}_{\text {hitung }}$ sebesar 6,681, dengan $\mathrm{dk}$ atau derajat kebebasan sebesar 63 yang didapat dari (df) = n-k-1 atau (65-1-1) dan didapat $t_{\text {tabel }}$ sebesar 1,998. Maka analisis uji $t$ tersebut dapat dituliskan dengan $t_{\text {hitung }}(6,681)>t_{\text {tabel }}$ $(1,998)$, sedangkan nilai signifikansi yaitu $0,000<0,05$ maka dapat disimpulan bahwa Ho ditolak dan Ha diterima, yang artinya terdapat pengaruh yang signifikan antara penerapan sistem $e$-filling terhadap kepatuhan wajib pajak di KUPUS II DITKUAD secara parsial.

Penelitian ini sejalan dengan teori yang dekemukakan oleh Abdul Rahman dalam (Lado \& M. Budiantara, 2018) yang menyebutkan bahwa faktor yang mempengaruhi tinggi rendahnya kepatuhan adalah besarnya biaya yang harus dikeluarkan oleh Wajib Pajak, serta waktu yang terpakai oleh Wajib Pajak dalam memenuhi kewajiban perpajakannya, mulai dari waktu membaca formulir SPT dan buku petunjuknya, waktu untuk konsultasi dengan akuntan atau konsultan pajak untuk mengisi SPT, serta waktu yang terpakai untuk pulang pergi ke kantor pajak.

Penelitian ini juga sejalan dengan penelitian Indri Setiyarini (2017), Yuliano Osvaldo Lado dan M Budiantara (2018), serta Gilbert Dwi Reinaldo Manullan, Putu Eka Dianita Marvilianti Dewi dan I Nyoman Putra Yasa (2020) yang dalam jurnalnya mengatakan bahwasannya Penerapan Sistem E-Filling berpengaruh positif signifikan terhadap Kepatuhan Wajib Pajak, namun penelitian ini tidak sejalan dengan penelitian Kartika Ratna Handayani dan Sihar Tambun (2016) dimana dalam jurnalnya menyebutkan bahwa Penerapan Sistem E-Filling tidak berpengaruh positif signifikan terhadap Kepatuhan Wajib Pajak yang dikarenakan pada tahun 2016 masih banyak wajib pajak yang belum menggunakan sistem $e$-filling itu sendiri. 
Maka dapat disimpulkan bahwa pada penelitian ini tinggi atau rendahnya penerapan sistem $e$-filling akan berpengaruh terhadap kepatuhan seorang wajib pajak. Serta semakin tinggi penerapan sistem $e$-filling maka akan semakin tinggi pula kepatuhan wajib pajaknya, sebaliknya apabila semakin rendah penerapan sistem e-filling maka akan semakin rendah pula kepatuhan wajib pajaknya.

\section{KESIMPULAN}

1. Berdasarkan hasil pengujian yang telah dilakukan menunjukkan bahwa penerapan sistem -filling pada pegawai KUPUS II DITKUAD sudah diterapkan sesuai dengan indikator-indikator.

2. Berdasarkan hasil pengujian yang telah dilakukan menunjukkan bahwa kepatuhan wajib pajak pada pegawai KUPUS II DITKUAD sudah diterapkan sesuai dengan indikator-indikator.

3. Berdasarkan hasil pengujian yang telah dilakukan menunjukan bahwa terdapat pengaruh signifkan antara penerapan sistem $e$-filling terhadap kepatuhan wajib pajak pada KUPUS II DITKUAD.

\section{DAFTAR PUSTAKA}

Kementerian Keuangan Direktorat Jenderal Pajak. (2017). Diambil kembali dari pajak.go.id: https://www.pajak.go.id/faq-laporan-tahunan

Firdaus, A. S. (2019). Penerapan E-Filing Terhadap Kepatuhan Wajib Pajak Orang Pribadi Dalam Penyampaian SPT Tahunan (Studi Kasus Pada KPP Pratama Pamekasan).

Humas Kemenkeu. (2021, Maret 8). Menkeu Imbau Wajib Pajak Lapor SPT Lewat EFILING. Diambil kembali dari setkab.go.id: https://setkab.go.id/menkeu-imbauwajib-pajak-lapor-spt-lewat-e-filing/

Kementerian Keuangan RI. (2018). Mudahnya Pelaporan Pajak Melalui E-filing. Diambil kembali dari Kementrian Keuangan RI: https://www.kemenkeu.go.id/sites/default/files/artikel_pajak_0312.pdf

Lado, Y. O., \& M. Budiantara. (2018). Pengaruh Penerapan Sistem E-Filling Terhadap Kepatuhan Wajib Pajak Orang Pribadi Pegawai Negeri Sipil Dengan Pemahaman Internet Sebagai Variabel Pemoderasi.

Mardiasmo. (2019). Perpajakan. Yogyakarta: Andi (Anggota IKAPI).

Noviani, B. (2018). Pengaruh Penerapan Sistem E-Filing Terhadap Kepatuhan Wajib Pajak Dengan Sosialisasi Perpajakan Dan Pemahaman Internet Sebagai Variabel Moderasi.

Nurlaela, L. (2017). Pengaruh Penerapan E-Filling Terhadap Kepatuhan Wajib Pajak di KPP Pratama Garut.

Pemerintah Indonesia. (2009). Undang-Undang Nomor 16 Tahun 2009 Tentang Ketentuan Umum dan Tata Cara Perpajakan. Jakarta: Sekretariat Negara.

Peraturan Direktorat Jenderal Pajak Nomor PER-47/PJ/2008 tentang Tata Cara Penyampaian Surat Pemberitahuan Dan Penyampaian Pemberitahuan Perpanjangan Surat Pemberitahuan Tahunan Secara Elektronik (E-Filing) Melalui Perusahaan Penyedia Jasa Aplikasi (ASP).

Peraturan Direktorat Jenderal Pajak Nomor PER-1/PJ/2014 tentang Tata Cara Penyampaian Surat Pemberitahuan Tahunan Bagi Wajib Pajak Orang Pribadi yang Menggunakan Formulir 1770S atau 1770SS Secara e-Filling Melalui Website Direktorat Jenderal Pajak (www.pajak.go.id). 
Peraturan Menteri Keuangan Nomor 74/KMK.03/2012 tentang Wajib Pajak dengan Kriteria Tertentu Dalam Rangka Pengembalian Pendahuluan Kelebihan Pembayaran Pajak.

Prastowo, Y. (2017, Maret 17). Diambil kembali dari online pajak: https://www.onlinepajak.com/tentang-efiling/modernisasi-administrasi-perpajakan-upayapenyempurnaan-pelayanan-pajak-bagian-1-1

Resmi, S. (2017). Perpajakan. Selemba Empat.

Santoso, Y. I. (2021, Maret 18). Diambil kembali dari Kontan.co.id: https://nasional.kontan.co.id/news/penerimaan-pajak-hingga-februari-2021mencapai-14493-triliun

Sugiyono. (2019). Metode Penelitian Kuantitatif dan R\&D. Bandung: Alfabeta.

Sujarweni, V. (2019). Statistik untuk Bisnis dan Ekonomi. Pustaka Baru Press. 